\title{
Fra Rambo-sperm til aggedronninger: To versioner af videnskabsfotografen Lennart Nilssons film om den menneskelige forplantning
}

Af Mette Bryld og Nina LyKKe

Videnskabsfotografen bag den beromte bog Et barn bliver til har udsendt en dokumentarfilm $i$ to versioner - en svensk og en amerikansk. Hvordan bliver køn, seksualitet, etnicitet, kroppe og familier konstruevet $i$ de to versioners fortallinger om karlighedsparret og om spermens mode med agget?
B illeder af æxg og sperm, der smelter sammen, af embryonale celledelinger, af fostre i forskellige størrelser og stillinger inde i fosterhinden er i løbet af de seneste årtier blevet en veletableret bestanddel af populærkulturen. Ingen studser idag over at se et sovende, tommelfingersuttende foster, omsluttet af sin beskyttende fosterhinde, optræde som frontfigur i en reklame for et flyselskab (Sabena). Og det befrugtede ægs delinger er på TV-kanalerne blevet så meget hverdagskost, at seerne ikke længere har brug for nærmere forklaringer på, hvad det egentlig er, der repræsenteres. Videnskabsdokumentariske fotos af forplantningsprocessen har ved deres ihærdige cirkulering i bøger, blade, film, TV, video og internet gjort kønsceller og embryoner til populærkulturelle ikoner med et egetliv.

Vi vil sætte fokus på denne udvikling og som analytisk prisme bruge to nyere videnskabsdokumentar-film om menneskelig forplantning. Den ene, Kärlekens Mirakel (2000), er en svensk produktion, lavet af 
Sveriges TV i samarbejde med en række europæiske TV-kanaler (blandt andet DR), et japansk TV-selskab og endelig med WGBH, Boston, en amerikansk public service kanal, hvis "science unit", NOVA, markedsfører sig som det mest sete videnskabs-TV i verden. Den anden, Life's Greatest Miracle (2001), er pikant nok det amerikanske TV-selskab, WGBH's og NOVAs egen - og anderledes - version af den svenske film.

Hvad vi vil analysere, er med andre ord to udgaver af "samme" film. For selv om de to har ret forskellige ideologiske budskaber, må de alligevel betragtes som varianter. Det, der forener dem, er, at hovednavnet bag begge er den verdensberømte, svenske videnskabsfotograf, Lennart Nilsson. Et delvist sammenfaldende billedmateriale fra "mesterfotografens" kamera, der endnu engang viser os epokegørende billeder af mødet mellem xg og sperm og fostrets vækst i kvindens livmoder, er - sammen med "brand"-navnet, "Lennart Nilsson" det fælles varemærke, der gør Kärlekens Mirakel og Life's Greatest Miracle til varianter snarere end til to separate værker.

Allerede i 1960erne skabte Nilsson sig et verdensnavn ved sine foto-dokumentarer om fostrets udvikling (Ett barn blir till (1965/1990) og Life (august 1965)). Siden har en række internationalt prisbelønnede videnskabsdokumentarfilm med stadig teknisk forbedrede optagelser af de reproduktive begivenheder i penis, testiklerne og ikke mindst livmoderen slået Nilssons navn fast $\mathrm{i}$ en bred offentlighed. Nilssons første film Så börjar livet/The Beginning of Life (1965) vandt f.eks. Prix Italia, og senere har han bl.a. vundet to Emmyer (den amerikanske TV-verdens Oscar) for hhv. Sagan om Livet/Miracle of Life (1982/ 1983) og trilogien Livets Mirakel/The Odyssey of Life (1996). Om Nilssons internationale berømmelse vidner også det, at Ett barn blir till er oversat til 20 sprog. Bogen er desuden kommet i nye udgaver og i oplag på oplag, og - som de to afbildede re- klamer (for Sabena og for sikkerhedsseler) viser - har dens billeder fået et ikonografisk egetliv. Reklamernes fosterbilleder er nemlig taget fra forsiden af den seneste udgave af bogen (Nilsson 1990). Er der ét navn, der er blevet forbundet med visualiseringen af den menneskelige reproduktions indre mikroverdener og med det 20. århundredes omdannelse af livmoderen til en offentlig skueplads, så er det Nilssons. Ja, hans billeder har i så høj grad fået status af monument over denne udvikling, at nogle af dem - et $æ g$-møder-sperm-billede og to fotos af det befrugtede $x g$ - endda er blevet sendt ud i universet med rumsonden Voyager i 1977. Sammen med en eksklusiv række af andre, omhyggeligt udvalgte billeder og lydsekvenser, der skal oplyse E.T. om mennesket på planeten, Jorden, vil Nilssons billeder stadig være på rumrejse om milliarder af år, når solen er død og Jorden forsvundet (Sagan 1978).

Vores mål med at se på de to udgaver af Nilssons seneste film er at diskutere, hvordan denne type populærvidenskabelige film om menneskelig reproduktion konstruerer køn, seksualitet, etnicitet, kroppe, familier og subjektivitet. Ikke mindst anglo-amerikanske feminister har kritiseret Nilssons billeder for at reproducere stereotype og gammeldags kønsbilleder, når de i forlængelse af den biomedicinske tradition for fremstilling af menneskelig forplantning tilskriver spermen Rambo-agtige kvaliteter, og når de personliggør fostret, mens moderen reduceres til en hovedløs container. Vi vil med artiklen opfordre hjemlige feminister og medieforskere generelt til at give populærvidenskabelige repræsentationer mere opmærksomhed. Billedernes udbredelse, popularitet og ikonografiske status gør det vigtigt at forholde sig til deres køns-, seksualitets- og etnicitetskonstruktioner.

Når vi vil introducere denne diskussion i Danmark netop med udgangspunkt i de to varianter af Nilssons seneste film - henholdsvis den svenske originalversion Kärlekens Mirakel og Life's Greatest Miracle, der 
er produceret specifikt for det amerikanske marked, - er det imidlertid, fordi vi samtidig med, at vi præsenterer den feministiske kritik, også vil erindre om, at den faktisk kan have konsekvenser! Det virker nemlig, som om manuskriptforfatteren til den amerikanske udgave, Julia Cort, har lyttet til de anglo-amerikanske kritikere. ${ }^{1}$ I hvert fald er fremstillingerne af $x g$, sperm, foster og forældre her ændret på en sådan måde, at de til en vis grad kommer denne kritik imøde.

Når den amerikanske udgave konstruerer køn, etnicitet, familie, kroppe, seksualitet og subjektivitet på en anden, mere "politisk korrekt" måde end den svenske, er der dog også andet end gode viljer på spil. Mens den svenske film er præget af tankegangen om statsfjernsynets pligt til "oplyse" og docere på en "neutral” scientistisk-positivistisk facon, har den amerikanske TV-industris markedsorientering med dens krav om noget "nyt" og "underholdende", der kan tiltrække seere, sat sig tydelige spor i Julia Corts redigering. Her drejer det sig ikke om at belære ved at docere, men om at undervise ved at underholde, det vil sige om det, der kaldes "edutainment". Målet med en videnskabsdokumentarfilm er, at den er "as entertaining as it is informative", som det hedder på NOVAs hjemmeside (www. pbs.org/wbgh/nova/about.html). Til edutainment hører interpellation: Filmens målgruppe skal, inden for normalspektret af hetero-par, kunne være hvem som helst. Ikke for rige eller for fattige, ikke for etniske, ikke for kvindelige eller mandlige, for unge eller gamle, men tværtom multikulturelle hybriditeter, der inkluderer noget multisocialt, multietnisk og multikønsligt. Med andre ord, et amerikansk norm-par, hvis idealitet ligger $\mathrm{i}$ deres evne til at udviske forskelle. Der er tydeligvis i redigeringen af den amerikanske film tænkt meget over, hvordan denne hybriditet realiseres i de identifikationsfigurer, som filmen tilbyder seerne. Et edutainment-perspektiv har dog uden tvivl også ligget de svenske producenter på sinde, men er meget mere integreret og gennemtænkt i fremstillingsformen hos det amerikanske TV-selskab.

For at illustrere vores pointer både om den feministiske kritiks eventuelle effekter og om markedsorienteringens betydning vil vi se nærmere på, hvordan historien om æg, sperm, embryoner, fostre og forældre er fortalt i de to film. Artiklen er struktureret som en nærlæsning af filmene. Vi vil starte med at se på lighederne og derefter diskutere forskellene. Allerførst vil vi dog give en kort introduktion til den teoritradition Feminist Cultural Studies of Science/feministisk kulturanalyse af teknovidenskab - , som vores analyse er funderet $\mathrm{i}$.

\section{FEMINISTISK KULTURANALYSE}

AF TEKNOVIDENSKAB:

\section{ANALYSENS TEORETISKE RAMME.}

Som en række andre - primært anglo-amerikanske - feministiske analyser af Nilssons billeder og af populærvidenskabelige forplantningsfremstillinger generelt (for eksempel Martin 1991, Stabile 1992, Duden 1993, Haraway 1997, Franklin, Lury \& Stacey 2000) er vores analyse baseret på den gren af feministisk forskning, som på engelsk kaldes "Feminist Science Studies". Specielt bygger vi på en variant af denne, feministiske kulturstudier af teknovidenskab, som er dannet i et teoretisk skxringspunkt mellem kulturstudier ("Cultural Studies"), teknovidenskabsstudier ("Science and Technology Studies, STS") og feministisk forskning. Som beskrevet for eksempel i Lykke og Braidotti (1996) er "Feminist Science Studies" et produkt af årtiers feministisk kritik af natur- og teknovidenskabens fremstillinger af køn. Det er en kritik, som har udviklet sig i tret samspil med socialkonstruktionistiske forståelser af såvel

\section{Reklame for flyselskabet Sabena, bragt $i$ tids- skriftet National Geographic april 1998 s. 2.}




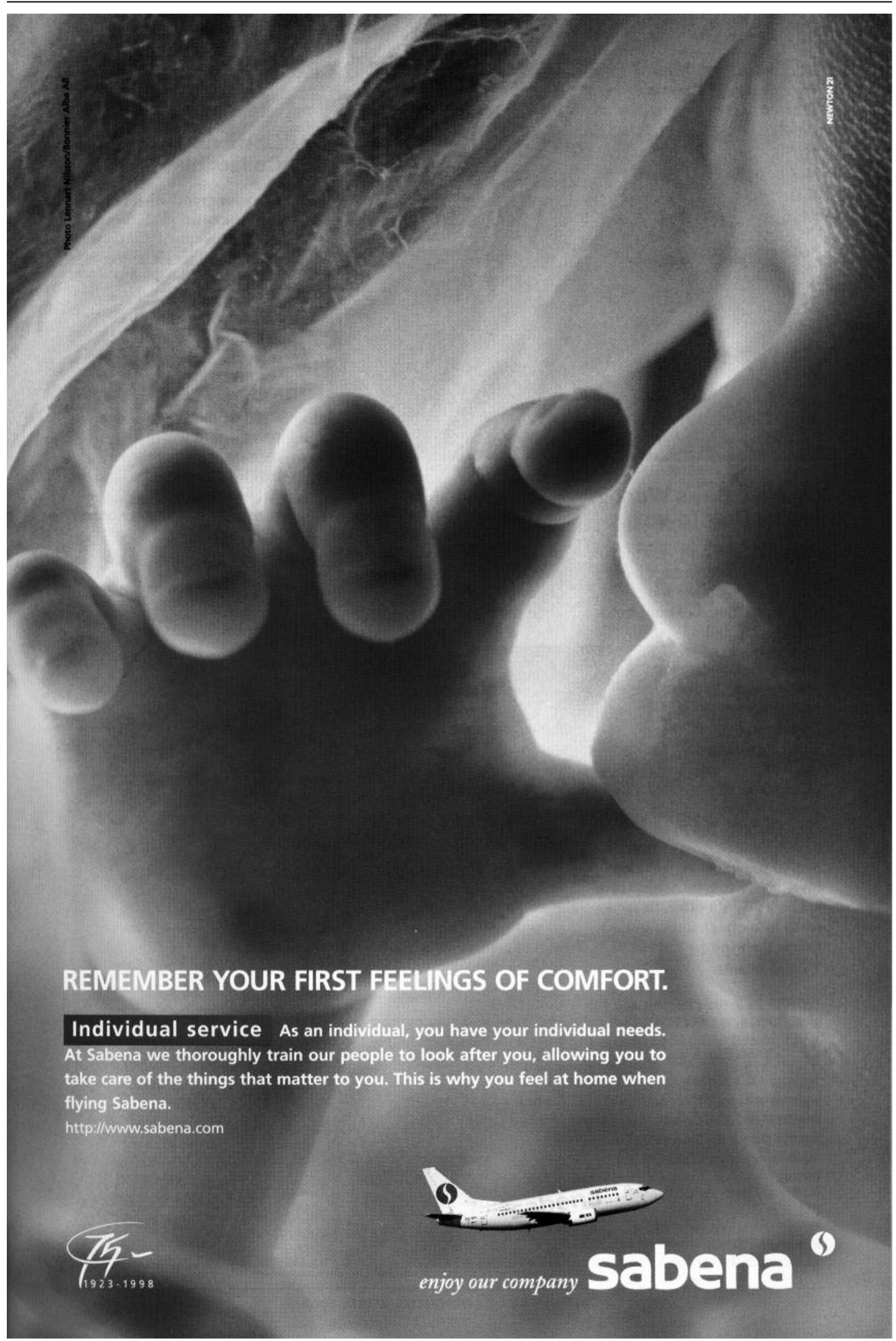


køn som videnskab. I synergi med feministiske kulturstudier ("Feminist Cultural Studies", se f.eks. Thornham 2001), der gennem mange år har haft populærkulturen $\mathrm{i}$ fokus, har den gren af "Feminist Science Studies", som vi beskæftiger os med her, nemlig feministiske kulturstudier af teknovidenskab, kigget specielt på populærvidenskaben og på populærmediernes formidling af natur- og teknovidenskabens budskaber.

Som udbredelsen af Nilssons billeder klart demonstrerer, er populærvidenskaben i lige så høj grad en del af populærkulturens billedmaskiner som sæbeoperaer eller harlekinromaner. Begge slags populærkultur er med til at forme de ikonografier, fortællinger, plotstrukturer, diskurser med videre, som udgør det, der inden for kulturstudierne kaldes det kulturelt imaginære (se Dawson 1994, 48); det vil sige de forestillingsverdener, som kulturelle fællesskaber spejler sig i og danner identitet på baggrund af. Selv om der selvfølgelig er forskel på populærfiktionens kulørte historier og populærvidenskaben, som påberåber sig naturvidenskabens autoritative og "objektive" fremstillingsmodus, kan begge genrer ifølge feministiske og socialkonstruktionistiske kulturanalytikere betragtes som fortællinger - som melodramaer, som romantiske fortællinger, som action-historier og så videre, der giver næring til de kulturelt imaginære forestillingsverdener. Set ud fra en socialkonstruktionistisk forståelsesramme kan både naturvidenskaben og dens populærvidenskabelige formidlinger nemlig forstås som "a story-telling practice" (Haraway 1989, 4-5).

Metodisk betyder dette udgangspunkt, at det bliver interessant at analysere (populær)videnskabelige fremstillinger ved hjælp af analysemåder og metodologier, som kommer fra for eksempel litteratur-, filmog medievidenskab (Bryld og Lykke 2000). Det er denne type tilgang, vi anvender i den følgende, feministisk-ironiske nærlæsning af de to varianter af Nilssons film.
KÄRLEKENS Mirakel OG LIFE'S Greatest Miracle: Ligheder

De to filmvarianter indskriver sig som Nilssons øvrige produktion i videnskabsdokumentargenren. Begge kan henregnes til det, der kaldes "the expository documentary" (Kilborn og Izod 1997), det vil sige den klassiske undergenre af dokumentarfilmen, som bygger på den genrekonvention, at der er tale om "dokumentarisme", forstået som en mimetisk repræsentation af den "virkelige" virkelighed. Denne type videnskabsdokumentarer er forankret i en positivtisk epistemologi - og i dens tro på kameraet som middel til at lave objektive og sande repræsentationer af en ikke-konstrueret virkelighed. Postmoderne fotografiteori såvel som kulturkritiske og feministiske videnskabsstudier har undermineret denne positivistiske selvforståelse - og understreget, hvordan både fotografiet og de objekter, som naturvidenskaben beskæftiger sig med, rummer dimensioner af diskursiv konstruktion. Disse synspunkter har imidlertid ikke påvirket videnskabsdokumentargenrens producenter i synderlig grad. De lægger sig som regel tæt op ad naturvidenskabens positivistisk tænkende mainstream. Det er for eksempel stadig normen, at en autoritativ voice-over i et sprog, der prætenderer videnskabelig "neutralitet", kommenterer de objekter, billedsiden fremviser, som om det biomedicinske fotografi var et medium, der kan give os et helt transparent vindue til verden "derude" eller snarere "derinde" - i kroppen. Nilssons film er ingen undtagelse. Såvel hans tidligere produktioner som de nyeste Kärlekens Mirakel og Life's Greatest Miracle har en fortællerstemme, hvis autoritative udlægning af billederne understøttes af creditlisten, der altid hos Nilsson opregner en lang række videnskabelige eksperter. Med deres navne borger disse eksperter for filmenes videnskabelige kvalitet og objektivitet.

Ved siden af det fælles tilhørsforhold til den klassiske dokumentargenre, som tilskriver tekst og billeder status af objektiv, 
"neutral", videnskabeligt korrekt og transparent beskrivelse, er filmene også meget ens i deres formelle opbygning. Hovedhistorien $\mathrm{i}$ alle Nilssons film om menneskelig reproduktion har helt fra Så börjar livet i 1965 været skåret over samme læst. Første del af filmfortællingen sætter fokus på mødet mellem æg og sperm. Vi følger sædcellerne fra ejakulationen og xgcellen fra ægløsningen frem til højdepunktet, deres møde med hinanden. Anden akt i det faste skema handler om udviklingen fra de første celledelinger i det befrugtede $x g$ til fødslen.

Som ramme om denne rapport fra en kropslig mikroverden, som avanceret medicinsk udstyr og sofistikerede visualiseringsteknologier har gjort synlig for os, er der i alle filmene indklippet billeder, der illustrerer befrugtning, graviditet og/eller fødsel i normalverdenens makroperspektiv. Her ser vi som minimum et billede af selve fødslen, men siden Nilssons første film (Nilsson 1965 ) er denne ramme med TV-mediets udvikling udvidet kraftigt i den populære belærings og underholdnings tjeneste. I de seneste film er der tale om en egentlig rammefortælling med en selvstændig handling. Både Kärlekens Mirakel og Life's Greatest Miracle præsenterer os for en historie om et heteroseksuelt par: de vordende forældre. Hovedhistorien er stadig den om begivenhederne på mikroniveauet; rammen har imidlertid fået meget mere plads og indholdsmæssig fylde. Mest i den amerikanske version, hvor "edutainment"-perspektivet er stærkest, men også i den svenske er historien om parret markeret som et sammenhængende forløb af indklippede scener. Med denne rammefortxlling om parret konstrueres en kontekst omkring mikroniveau-fortxllingen, som i begge varianter understreger deres karakter af diskursiv konstruktion. Hvor genrekonventionerne og voice-over'ens scientistisk-belærende udlægning får det videnskabsfotografiske billedmateriale af begivenhederne i testikler, penis, xggestokke og livmoder til at fremstå som "neutral og objektiv videnskab", så blotlægger rammefortælllingen om parret til gengæld de diskurser, der er på færde.

Parret er i begge film representeret som det normale, heteroseksuelle par, hvis gensidige kærlighed og lykke spontant får dem til at opfylde deres genetiske programmering til at reproducere sig. Som vi vender tilbage til, er parfremstillingen i de to versioner forskellig: den svenske sætter et romantisk-mytisk kærlighedspar i centrum, mens det amerikanske par repræsenterer en mere hverdagsrealistisk æxteskabelig lykke. Men vigtige fællesnævnere er kærlighed, lykke - og heteronormativitet. Den hegemoniske normativitet giver sig i begge film til kende ved, at der er tale om parfigurer, som på hver deres måde skal repræsentere "alle og enhver", og hvis fremtoning og måder at agere på naturaliseres ved sammenknytningen med mikroniveau-fortællingen, der utvetydigt tematiserer biologisk determinisme og genetisk essentialisme. Endnu en lighed mellem filmene er nemlig, at der i begge er et tydeligt hierarki mellem makro- og mikroniveaufortællingen. Den autoritative voice-over's kommentarer lader os ikke i tvivl om, at det er den "objektivt videnskabelige" beretning på mikroniveauet, som rummer de egentlige forklaringer af, hvad der foregår, og budskabet her er meget klart i begge film.

Som optakt - før præsentationen af parret - lægger den amerikanske film ud med bramfrit at slå fast, at hvad det hele handler om, er det, der foregår på mikroniveauet: "under the skin", hvor DNAet og generne regerer. Mens kameraet panorerer hen over menneskemylderet på en strand, belærer speakeren os om "the urge to procreate":

You might think all the people on this beach are just working on their suntans. But beneath all that sunscreen, under the skin, there's a frenzy of activity. Without even thinking about it, almost all adults here are busy trying to reproduce. They can't help themselves. 


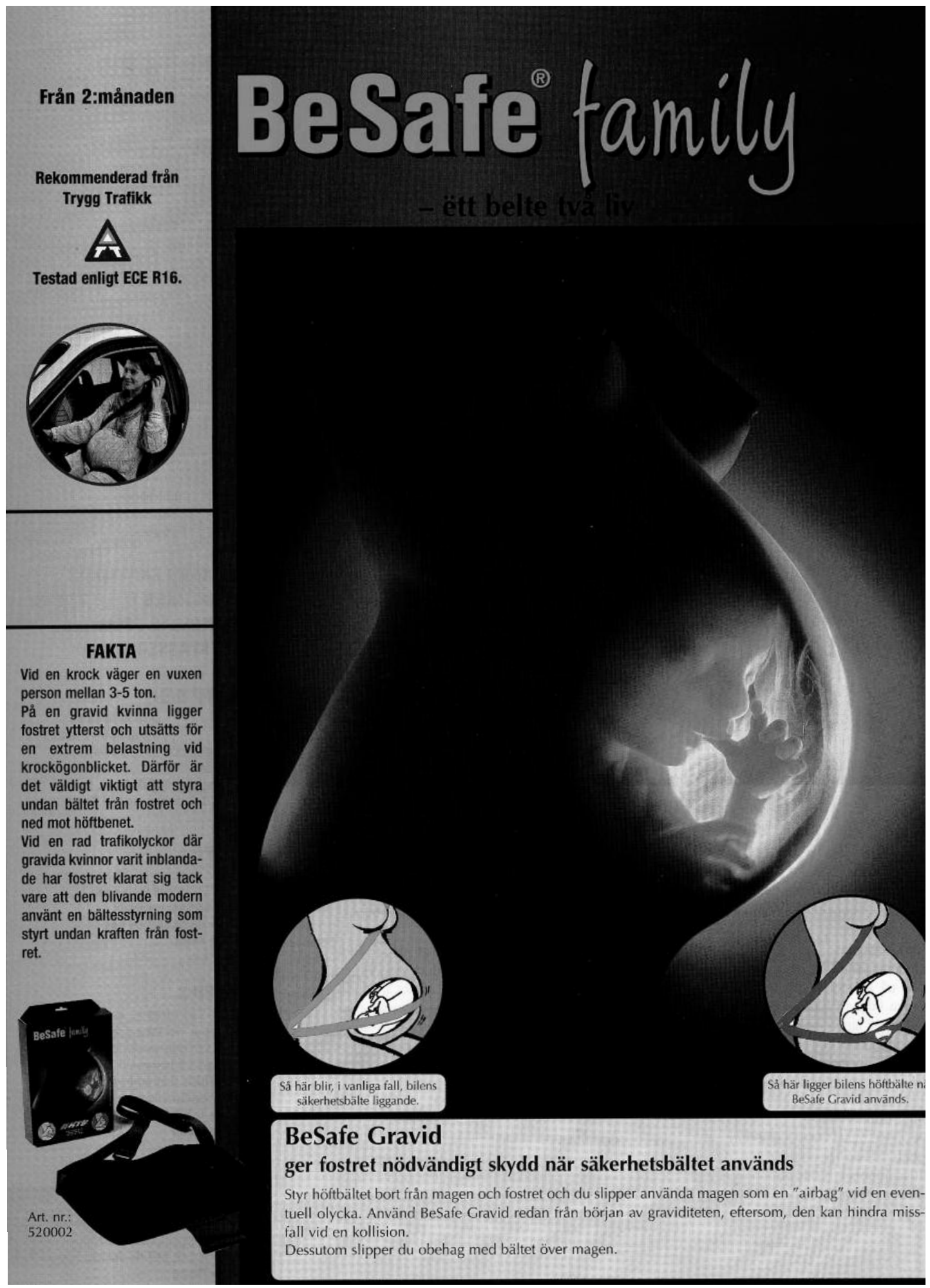

Reklame for sikkerhedsselemerket BeSafe family 
The urge to procreate is a fundamental part of life, not just for us but for all life.

I den mindre edutainment-bevidste svenske film er hierarkiet mellem rammen og historien på mikroniveauet endnu tydeligere. Her fremstår rammehistorien mest som staffage, der er klippet ind for at vække et søvnigt TV-publikums interesse for de "egentligt" videnskabelige budskaber, som også omhandler "the urge to procreate". Det romantiske par er "i virkeligheden" blot drevet af deres genetiske programmering.

\section{KäRLEKENS MiRAKEL OG LIFE'S Greatest Miracle: ForSKELle}

Selv om der er klare lighedspunkter mellem de to versioner, er forskellene nok så påfaldende. Det gxlder, hvad enten vi ser på udformningen af fortællingen om parret, eller vi vender blikket mod filmenes koreografering af kønscellernes dans i kvindekroppens indre. På begge niveauer, makro- såvel som mikronivau, er udsigelserne vidt forskellige i de to film. Lad os se først på forskellene mellem rammefortællingerne for derefter at gå over til mikroniveauet.

\section{Rammehistorierne}

I den svenske originalversion gives historien om det lykkelige heteropar universelle, romantisk-mytiske og noget nær religiøse dimensioner (Lykke \& Bryld 2002). Filmen åbner med et billede af et foster, som fører sine hænder mod hinanden, mens speakeren med en nærmest religiøs patos fortæller om skabelsen af barnet som "et af jordelivets mirakler". Billedet glider fra fostrets hænder over i et bryllupsbillede, hvor gommen sætter ringen på brudens finger. Samtidig hører vi, at skabelsen af barnet "Ofte begynder (...) sådan her: to mennesker vil dele livet med hinanden og håber, at de vil få børn sammen." Efter dette bombastiske anslag til en romantisk-religiøs fortælling om det universelle kærlighedspar følger vi i korte klip parret gennem et forløb, der er centreret om mytens absolutte highlights: optakten til parrets (første?!) samleje, romantisk placeret på en strand; deres første fælles glæde ved at "se" barnet i ultralydscanningen; og endelig på hospitalet under fødslen, som forløber meget-meget let, smertefrit og "naturligt"(!). Slutscenen viser mor og barn ude i naturen, og som for at understrege de mange fototekniske scoops, filmen gør sig til af, ser vi, der nu er placeret inde i babyens mund, hvordan mælken sprøjter ud af moderbrystet. Det er næsten som om, vi selv er lagt til at die hos den lyse, svenske natur-moder!

Parrets mytisk-ikonografiske status understreges af, at de er unavngivne, mangler subjektivt perspektiv og egenstemmer samt af det generelle fravær af kontekst i historien. Desuden spilles rollerne som Han og Hun af to skuespillere, der i Sverige er så kendte, at i hvert fald svenske seere er klar over, at det, de ser på tv-skærmen, blot er et iscenesat rollespil, som i al sin romantiske glamour lige så godt kunne være en sæbe-reklame. For renhed, hvidhed og ulastelighed er just de kvaliteter, det "naturlige" og lykkelige par udstråler. Hvad den svenske film vil vise os med dette par er med andre ord en kopi af det abstrakte menneske. Eller måske rettere, en repræsentation af vores art, mennesket, etnocentristisk forstået som et hvidt, velstående, yngre heteroseksuelt par, hvor de to "halvdele", Hun og Han, komplementerer hinanden i overensstemmelse med den borgerlige norm. Kønsidentiterne er således klare og velafgrænsede. Han er den aktive og udadfarende, Hun den passive og modtagelige. Det er Ham, vi ser sætte ringen på Hendes finger, og Ham, der klæder Hende af ved optakten til bryllupsknaldet på stranden.

I kontrast til denne svenske patos og glamour repræsenterer kærlighedsparret i den amerikanske version en jordnær og hverdagslig xgteskabelig lykke. Rammehistorien er her centreret om det navngivne, 
multikulturelle par, - anglo-amerikaneren Melinda Tate Iruegas og "chicanoen" Sergio Iruegas. De fremstilles i en realistisk hverdags-dokumentarisk stil med vægt på et fænomenologisk oplevelsescentreret perspektiv. Modsat den svenske filmversion, hvor bryllupsknaldet automatisk fører til det "mirakel", at kærlighedsbarnet bliver til, har Melinda og Sergio været gift et stykke tid, før de, som de siger, nu føler sig parate til at fă børn. At graviditet er noget, der kan kontrolleres, antydes kraftigt af Melindas ord om, at de ikke har "passet nok på”. Graviditeten er altså delvist planlagt og delvist den overraskelse, som knytter sig til begrebet, kærlighedsbarn. Modsat den sociale velbjergethed, der karakteriserer svenskerne, tilhører Melinda og Sergio, ligesom flertallet af amerikanere, endvidere det lidt ubestemmelige, lavere mellemlag. Noget ubestemmeligt ligger der også over deres kønsidentiteter. Melinda er en smule højere end manden, og det virker desuden, som om det er hende, der er familiens overhoved, idet Sergio tydeligvis ser op til hende og tager hendes meninger til sig. Mens Melinda således i relationen synes udstyret med en form for "mandlig" selvberoenhed og autoritet, er Sergio både psykisk og fysisk den bløde og "kvindelige", som det også signaleres af hans buttede krop, hvor ansatser til bryster gynger gennem t-shirten, når han går. På sin vis er han næsten lige så gravid som konen. Denne kønslige hybriditet kommer også til orde, når de fortæller om deres graviditetsoplevelser.

Vi følger dem igennem korte samtaler og filmklip, optaget i deres fælles hverdagsrum. I klippene fortæller Melinda og Sergio glade og lykkelige om svangerskabet i et hverdagsprog, der gør det let for seerne at opbygge en identifikation. På en pædagogisk måde præsenteres vi for de gode oplevelser og småproblemer, som formodes at være typiske for par, der venter deres første barn. Vi overværer først en snak om slægtsligheder, hvor albummet med familiefotos styrer diskussionen af, hvordan barnet mon vil komme til at se ud. Herefter følger vi kronologisk forløbet i graviditeten fra begyndelsen til slutningen, som det er oplevet fra begges synsvinkel. Vi hører for eksempel om den første svangerskabstid, hvor Sergio identificerede sig så stærkt med Melinda, at også han fik morgenkvalme. Vi făr et realistisk forvarsel om, at fødsler er smertefulde. Melinda fortæller om sit angstanfald ved tanken om, hvor lille skedeåbningen er i forhold til det barn, der skal komme ud af den. Endelig følger vi fødslen, hvor ikke blot Sergio, men også begge Melindas forældre er til stede. Ligesom historien lagde ud med familiebillederne og spørgsmålet om, hvem det nye skud på stamtræet ville komme til at ligne, slutter det således med at bekræfte familien som det nybagte forældrepars kontekst. Samtidig indeholder denne familiale kontekstualisering selv sagt en triviel ideologisk-politisk pointe med sin underforståede reference til USA som én stor, multikulturel familie.

\section{Mikroniveauets fortelling}

Har den amerikanske producent forsøgt at gøre rammehistorien mere "politisk korrekt" og mindre "altmodisch" i sin fremstilling af køn, familie, seksualitet, krop, subjektivitet og etnicitet, så gælder det i lige så høj grad for den måde, kommentaren til mikroniveauets fortælling er tilrettelagt på i de to versioner. Også her er der markante forskelle.

Først og fremmest repræsenterer den amerikanske version af første akt af mikroniveau-fortællingen et decideret brud med en utrolig sejlivet retorisk tradition for biomedicinsk reproduktionsfremstilling, som Emily Martin (1991) meget vittigt har kritiseret i en berømt artikel om retorikken i videnskabelige fremstillinger af $\mathfrak{x g}$-mødersperm-figuren. Alle Nilssons øvrige produktioner (inklusive Kärlekens Mirakel) skriver sig ind i denne gammeldags-fallocentriske fremstillingstradition, når de konstruerer spermen som en Rambo (Stabile 1992), der foretager en eventyrlig helterej- 
se for til sidst at blive belønnet med den passivt ventende xgprinsesse. Der er sket visse diskursive moderniseringer i Kärlekens Mirakel, hvor ægcellens proteiner trods alt skal acceptere sædcellen, før den trænger ind, men hele plottet er bygget op over "sperm-armadaens" helterejse med dens "kraftværker" (de mandlige arveanlæg). Al aktivitet og dramatik er retorisk og narratologisk henlagt til spermen. Ægget er derimod beskrevet i passivformer (det "transporteres" etc.) og i et funktionelt sprog (for eksempel “æggeledertrakten forsøger nu at få xgget ind...”) - et sprog, der stikker stærkt af mod de militært-heroiserende metaforer, som anvendes i beskrivelsen af sædcellen ("armada", "fremrykning", "fænomenale svømmere", "kamp for overlevelse", “vinderen" og så videre).

På baggrund af den tunge fallocentriske tradition, som knytter sig til fortællingen om mødet mellem $x g$ og sperm, er det bemærkelsesværdigt (ja, måske ligefrem et diskursivt "mirakel"!), at rollerne i Life's Greatest Miracle nærmest er byttet om. Her er det xgcellen og kvindens krop, der styrer showet. De fotografiske optagelser er langt hen de samme som i Kärlekens Mirakel, men speakerfortællingen konstruerer forløbet på en markant anderledes måde. Dens fremadskriden er både grammatisk og i plotstrukturen bundet op på, at de kvindelige elementer er subjekter i processen. De styrer spermens færd ved at "propel”, "alter", "order", "draw the entire contents of the sperm inside" etc. Når spermen endelig gør noget aktivt som for eksempel at svømme gennem xggelederen, så får vi straks at vide, at det ikke er Rambo-svømmerne, der făr succes. Det gør derimod "the slowpokes", som bliver fanget i æggelederens fimrehår for herefter "gradvist" at blive "sluppet fri”. Modsat de sædceller, der bare pisker derudaf, har de langsomme den bedste chance for at blive forandret på en sådan måde af kvindekroppen, at de senere kan accepteres af ægget. Det understreges også, at ægget kun lukker spermen ind i sig, hvis det og dets følge af "picky" "support cells" vil; "brute force alone" hjælper absolut ikke spermen. Det er det matriarkalsk dronningeagtigt beskrevne $æ g$, der sætter dagsordenen - som en spejling af makroniveauets fremstilling af Melinda som den, der bestemmer mest i parforholdet.

Til denne overordnede forskel i mikroniveau-fortællingen i henholdsvis Kärlekens Mirakel og Life's Greatest Miracle lægger sig en anden, nemlig at DNAet og dets agens er fremhævet meget mere i sidstnævnte. Selv om “æggedronningen" har făet tildelt en betydningsfuld rolle, så er den overordnede agens i filmens skabelsesberetning lagt hos det i sig selv ikke-kønsspecifikke DNA. "The urge to procreate" henføres fra starten af Life's Greatest Miracle til DNA'et i dets egenskab af et "molecule that carries our genes". I sidste instans er det altså hverken det kvindelige eller det mandlige element, som i fortællingen er bærer af det afgørende igangsættende moment, men derimod det basale og for alt liv fælles DNA. Der er en undertone af demokratisk ligestillingsdiskurs på færde, der klart adskiller sig fra fremstillingen i Kärlekens Mirakel. I den svenske original er DNA'ets rolle ikke betonet på nær samme markante måde som i Life's Greatest Miracle. Det har formentlig blandt andet den teknisk-æstetiske årsag, at de forklaringer af DNAets rolle, som gives i den amerikanske film, kræver computeranimerede illustrationer - og computeranimationer er reduceret til et minimum i den svenske original, der bevidst dyrker "mesterfotografens" unikke håndværk. Men det manglende fokus på den overordnede agens hos det ikke kønsspecifikke DNA styrker ikke desto mindre det fallocentriske perspektiv. Den basale agens i skabelsesberetningen i Kärlekens Mirakel bliver koncentreret i sædcellerne som en spejling af den patriarkalske seksualitetsfremstilling på makroniveauet, hvor Han er initiativtageren.

Den sidste forskel, vi vil nævne, omhandler repræsentationen af moderen og moder- 
kroppen - og koblingen mellem anden akt af mikroniveau-fortællingen og rammehistorien. "Clouene" i anden akt af fortællingen på mikroniveauet består i samtlige Nilsson-film af nærbilleder, der viser stadigt mere udviklede fostre. De er fotograferet, så de ser ud som “rumvæsner”, der svæver vægtløst omkring på en kosmisk udseende baggrund (Duden 1993), der ikke har meget lighed med livmoderens vægge. At livmoderen er fraværende har sine særlige grunde: Materialet til de fleste billeder er nemlig aborter, der kun på grund af konteksten kommer til at fremstå, som var de portrætteret i levende live. Enkelte billedsekvenser viser dog faktisk levende fostre, filmet inde i livmoderen med specialteknikker. Men end ikke her ser vi meget til (liv)moderen. Som den feministiske kritik har understreget, er moderen fremstillet som en container, vi tilmed knap nok får at se. Mikroniveau-fortællingens fokus og centrum er klart fostret.

Igen er det sådan, at Kärlekens Mirakel reproducerer denne tradition, mens Life's Greatest Miracle bryder den - ikke så radikalt som i æg-møder-sperm-figuren, men et vist opbrud er der trods alt tale om. For det første er der færre fosterbilleder i Life's Greatest Miracle, hvor rammehistorien generelt fylder meget mere. For det andet betyder også det fænomenologiske perspektiv, som anlægges i rammehistorien, at fremstillingen af den objektiverede moderkrop på mikroniveauet så at sige kontekstualiseres og indrammes af Melindas beretning om sine graviditetsoplevelser. For det tredje har de to xndringer tilsammen den effekt, at kontrasten mellem et personliggjort, superaktivt foster og en passiviseret og objektiveret moder nedtones.

\section{KONKLUSION}

Når vi foreslår, at forskellene mellem de to filmversioner blandt andet skyldes, at den amerikanske manuskriptforfatter har lyttet til de anglo-amerikanske feminister, er det, fordi Life's Greatest Miracle er xndret på netop nogle af de områder, der har været hovedpunkter i den feministiske kritik. Det etnisk hvid-hvide par med den patriarkalske rollefordeling er blevet udskiftet og moderniseret; det samme er myten om Rambospermen og beskrivelsen af moderen som en blot hovedløs container for et personliggjort foster.

Men hertil kommer, at Life's Greatest Miracle bevidst fremhæver det retoriske brud med den gammeldags-fallocentriske sperm-historie ved eksplicit at lade speakerteksten afskrive den med et "nothing could be further from the truth". I overensstemmelse med filmens scientistiske selvforståelse fremstilles det retoriske skift som et udtryk for videnskabelige landvindinger. Men at det også handler om at "sælge" filmen til et publikum, der er blevet træet af den fortærskede og infantile Rambo-historie, skinner tydeligere igennem, når også PR-materialet for Life's Greatest Miracle sætter fokus på netop dette skift:

Among the stunning new sequences shot by Nilsson is the incredible voyage of the sperm toward the egg. Sperm are often portrayed as brave warriours forging their way through hostile terrain, racing to overcome impossible odds, where the fastest and most powerful will conquer all and vanquish the egg. Nothing could be further from the truth. The journey of the sperm is controlled to a great extent not by the sperm itself, but by the woman. (PROMO før TV-premieren i USA d. 20.11.01, www.ptvpromo.org/programinfo/109/nova_lifes_miracle.html).

Netop omkring "salget" af repro-film som Kärlekens Mirakel og Life's Greatest Miracle har det markedsorienterede WGBH/NOVA sikkert en interesse $\mathrm{i}$ at lytte til feministerne. De skolelærere, vordende mødre med videre, der skal købe NOVAs videoer, er langt hen selvstændige, lønarbejdende kvinder. De udgør en gruppe af konsumenter, som, hvad enten de er feminister eller ej, 
repræsenterer et behov for fornyelse af kvindebilleder og kønsstereotype fremstillinger. Et behov, fiktionsfilmen længe har haft øje for ("Thelma og Louise" m.fl.). For at nordiske videnskabsfilmproducenter skal begynde at tage disse trends alvorligt, kræver det dog åbenbart, at vi i vores del af verden begynder at råbe op om disse dybt forældede "videnskabelige" fremstillinger.

\section{NoTe}

1. Sammen med Bo G. Erikson står Julia Cort bemærkelsesværdigt nok også som manuskriptforfatter til den svenske udgave. Der er dog næppe tvivl om, at Erikson har afstukket kursen. Han har siden 1970erne været manuskriptforfatter til og producent af Nilssons film, som han også har præsenteret og introduceret i sit tv-program, "Vetenskapens Värld" (jvf. Furhammar 1997, 187-188 og 217f.). Erikson har desuden indtalt den svenske version.

\section{LITTERATURLISTE}

- Bryld, Mette og Nina Lykke (2000): Cosmodolphins: Feminist Cultural Studies of Technology, Animals and the Sacred. London: ZED Books.

- Dawson, Graham (1994): Soldier Heroes. British Adventure, Empire and the Imagining of Masculinities. London, New York: Routledge.

- Duden, Barbara (1993): Disembodying Women.

Harvard University Press.

- Franklin, Sarah, Celia Lury and Jackie Stacey (2000): Global Nature, Global Culture. London: Sage.

- Furhammar, Leif (1997): Med TV i verkligheten. Sveriges Television och de dokumentära genrerna.

Borås: Stiftelsen Etermedierna i Sverige.

- Haraway, Donna (1989): Primate Visions. Gender, Race and Nature in the World of Science. New York, London: Routledge.

· Haraway, Donna (1997): Modest_Witness ${ }^{\circledR}$ Second_Millenium. FemaleMan ${ }^{(}{ }_{-}$Meets_OncoMou$s^{\mathrm{TM}}$. Feminism and Technoscience. New York, London: Routledge.

- Lykke, Nina and Rosi Braidotti (red.) (1996): Between Monsters, Goddesses and Cyborgs. Feminist Confrontations with Science, Medicine and Cyberspace. London: ZED Books.

- Lykke, Nina og Mette Bryld (2002, under udgi- velse): "Kønsceller, mikrober og mariehøns: Videnskabsdokumentarens cyborg-blik", in Mette Bryld og Randi Markussen (red): Cyberkulturer \& rekonfigurationer. København: Samfundslitteratur. - Kilborn, R. og J. Izod (1997): An Introduction to Television Documentary: Confronting Reality. Manchester: Manchester University Press.

- Martin, Emily (1991): "The Egg and the Sperm: How Science Has Constructed a Romance Based on Stereotypical Male-Female Roles", in Signs 16 (3): 485-501.

- Nilsson, Lennart (1965/1990): Ett barn blir till. Stockholm: Bonniers (dansk udg. 1966).

- Nilsson, Lennart (1965): Så börjar livet. Sveriges TV.

- Nilsson, Lennart (1965): "The Drama of Life before Birth", in Life (30. april).

- Nilsson, Lennart (1982): Sagan om Livet. Sveriges TV.

- Nilsson, Lennart (1983/1986): The Miracle of

Life. WGBH Boston: NOVA.

- Nilsson, Lennart (1996): Livets Mirakel, Sveriges

TV (serie i 3 dele. Udsendt som videoer under fællestitlen Livets Uppkomst).

- Nilsson, Lennart (1996): The Odyssey of Life.

WGBH Boston: NOVA.

· Nilsson, Lennart (2000): Kärlekens Mirakel. Sveriges TV (vist 10. 1. 2000; DR2 under titlen

Karlighedens Mirakel, d. 6.10.2001).

- Nilsson, Lennart (2001): Life's Greatest Miracle. WGBH Boston: NOVA.

- Sagan, Carl m.fl. (1978): Murmurs of Earth. The Voyager Interstellar Record. New York: Random House.

- Stabile, Carol A. (1992): "Shooting the Mother: Fetal Photography and the Politics of Disappearance", in camera obscura 28: 179-205.

- Thornham, Sue (2001): Feminist Theory and Cultural Studies. London: Arnold.

\section{SUMMARY}

The article analyses a recent science documentary TV-film on human reproduction which has come out in two different versions, an original Swedish one, entitled Kärlekens Mirakel (The Miracle of Love) (2000), and an American NOVA re-make, Life's Greatest Miracle (2001). Both documentaries are based on photography by the famous Swedish photographer, Lennart Nilsson. Contra- 
ry to what might be expected, the US version is by far the most "political correct" in its construction of both the love story on the film's macro-level and the sperm-meet-egg narration on its micro-level. The article suggests that the Anglo-American feminist critique of the traditional biomedical representations of the sperm as heroic warriors in quest of the passive egg may eventually have stimulated the US production company to this rhetoric shift. However, the old-fashioned and fallocentric discourse of the Swedish film indicates that Nordic feminists should pay much more attention to science documentaries on human reproduction.

Mette Bryld, mag.art. lektor ved Institut for Litteratur, Kultur \& Medier, Syddansk Universitet

Nina Lykke, dr. phil., professor ved Tema Genus, Institutionen för Tema, Linköpings Universitet 